\title{
Dietary conjugated linoleic acids affect tissue lipid composition but not de novo lipogenesis in finishing pigs
}

\author{
Giuseppe BEE* \\ Swiss Federal Station for Animal Production, Posieux, 1725, Switzerland
}

(Received 15 March 2001; accepted 28 September 2001)

\begin{abstract}
Dietary conjugated linoleic acids (CLA) have been reported to profoundly affect lipid metabolism and to act as repartitioning agents. Currently, little is known about their effect on the fatty acid profile of tissue lipids in pigs. In the present study we determined the lipid composition of the backfat inner (BFI) and outer layer (BFO), omental fat (OF) and intramuscular fat (IMF) of the longissimus dorsi muscle in 24 Swiss Large White pigs fed diets supplemented either with $2 \%$ CLAenriched oil (containing $58.9 \mathrm{~g}$ CLA isomers $100 \mathrm{~g}^{-1}$ of total fatty acids), linoleic acid-enriched oil (SO), or lard (LA). Animals were individually penned at $70 \mathrm{~kg}$ live weight and fed $2.8 \mathrm{~kg} \cdot \mathrm{d}^{-1}$ of the respective diet to slaughter at $105 \mathrm{~kg}$. Growth performance, carcass characteristics and muscle measurements were not significantly affected by the dietary fats, although average daily weight gain and feed conversion ratio tended to be numerically improved 5-7\% in the CLA-fed pigs compared to pigs of the other two treatments. Independent of the tissue, pigs fed the CLA diet exhibited higher levels of saturated fatty acids $(P<0.05)$ and lower levels of monounsaturated fatty acids $(P<0.05)$. By contrast, there was no difference in the distribution pattern of the saturated fatty acids between the LA and SO groups, but pigs fed the SO diet had lower monounsaturated and higher polyunsaturated fatty acid levels compared to those fed the LA diet. The CLA content of the BFO, BFI and OF was similar and did not indicate a preferential incorporation in one of the tissues. Compared to the adipose tissue, approximately $67 \%$ lower total CLA concentrations were found in the IMF. The in vitro activity of lipogenic enzymes was not altered by the dietary fat suggesting that lipogenesis was not affected by CLA. The distinct shift towards higher deposition of saturated fatty acids and lower deposition of monounsaturated fatty acids indicated a potential down-regulation of $\Delta 9$-desaturase activity by dietary CLA.
\end{abstract}

pig / CLA / fatty acid composition / adipose tissue / loin muscle

Résumé - Influence de l'apport des acides linoléiques conjugués dans l'alimentation sur la composition des tissus adipeux et la lipogenèse de novo chez les porcs en finition. Plusieurs travaux ont révélé que les acides linoléiques conjugués (conjugated linoleic acids : CLA) ont une influence importante sur le métabolisme des lipides et des protéines. En revanche, les effets des

* Correspondence and reprints

Tel. +41 2640772 22; fax: +41 2640772 00; e-mail: giuseppe.bee @ rap.admin.ch 
CLA sur le profil des acides gras dans les tissus adipeux chez le porc sont peu connus. Dans cette étude, nous avons déterminé la composition du tissu adipeux dorsal interne et externe, du tissu adipeux omental et du tissu adipeux intramusculaire du muscle long dorsal (longissimus dorsi) de 24 porcs Swiss Large White. Ceux-ci ont reçu des rations complétées soit par de l'huile enrichie de $2 \%$ de CLA (58,9 g CLA isomères $100 \mathrm{~g}^{-1}$ d'acides gras totaux), de l'huile enrichie d'acide linoléique (SO) ou du lard (LA). D'un poids vif initial de $70 \mathrm{~kg}$, les animaux ont été gardés dans des boxes individuels et engraissés avec $2,8 \mathrm{~kg} \cdot \mathrm{j}^{-1} \mathrm{~d}$ 'aliment jusqu'à l'abattage à $105 \mathrm{~kg}$. La croissance, les caractéristiques de la carcasse et les dimensions du muscle n'ont pas été influencées d'une manière significative par les différents compléments de graisse. Nous avons observé tout de même une amélioration du gain de poids et de l'indice de consommation de 5 à $7 \%$ en moyenne chez les porcs ayant reçu une ration supplémentée avec des CLA par rapport aux porcs alimentés avec les deux autres rations. Indépendamment du tissu, les teneurs en acides gras saturés étaient plus élevées $(P<0,05)$ tandis que les teneurs en acides gras monoinsaturés étaient inférieures $(P<0,05)$ pour les porcs alimentés avec les CLA. Par contre, les teneurs en acides gras saturés étaient semblables entre les traitements LA et $\mathrm{SO}$, mais les porcs recevant la ration $\mathrm{SO}$ avaient des teneurs en acides gras monoinsaturés plus basses et des teneurs en acides gras polyinsaturés plus élevées que les porcs du groupe LA. Les teneurs en CLA du tissu adipeux dorsal externe et interne et du tissu adipeux omental étaient les mêmes, ce qui indique qu'il n'y a pas d'incorporation préférentielle de CLA. Comparée au tissu adipeux dorsal, la teneur du tissu adipeux intramusculaire en CLA était inférieure de $67 \%$. L'activité in vitro des enzymes lipogènes n'a pas été influencée par les trois types de suppléments de graisse, ce qui signifie que les CLA n'ont pas eu d'effets sur la lipogenèse. La déposition plus importante d'acides gras saturés et moins élevée d'acides gras monoinsaturés indique une réduction potentielle de l'activité de la $\Delta 9$-désaturase par les CLA.

porc / CLA / composition en acides gras / tissu adipeux / muscle long dorsal

\section{INTRODUCTION}

The knowledge that dietary fat composition influences the fatty acid profile and the quality of body fat in the pig is not novel [41]. Besides overall de novo fat synthesis, dietary polyunsaturated fatty acids (PUFA) play a determinant role in fat composition because they are readily deposited into the adipose tissue of pigs, whereas dietary saturated (SFA) and monounsaturated (MUFA) fatty acids have a weaker influence on fat composition. A high degree of unsaturation of pork fat caused by PUFA is undesirable for meat product manufacturers because high PUFA content results in meat products that are soft and have a reduced shelf life $[32,37]$. However, compared to linoleic acid [18:2(n-6)], the conjugated linoleic acids (CLA), a class of positional and geometric conjugated dienoic isomers of linoleic acid in which the constituent double bonds are separated by a single carbon-carbon bond, seem to affect those parameters differently. Feeding pigs a diet supplemented with CLA has been shown to positively affect belly firmness and marbling score [15]. Furthermore, Ostrowska et al. [27] reported that dietary CLA increases lean tissue deposition and decreases fat deposition in finisher pigs, confirming results of the first pig experiment with dietary CLA [14]. From the latter study, Kramer et al. [21] analyzed CLA isomer incorporation into lipid classes from inner backfat and omental fat and found that the distribution of CLA isomers in triacylglycerol was similar to that found in the diet. However in all these reports, the effect of incorporated CLA on the fatty acid pattern of tissue lipids was not determined. Therefore, the aim of the present experiments was to establish the extent to which the fatty acid pattern of adipose and muscle tissue lipids is influenced by feeding a commercially available CLA source to finishing pigs. We compared the effects due 
to CLA-enriched oil inclusion (2\%) to those induced by a linoleic acid-enriched oil or lard [where the primary fatty acid is oleic acid: 18:1(n-9)]. Additionally, we determined the effect of the dietary fats on the activity level of enzymes involved in the de novo fatty acid synthesis in the fat tissue.

\section{MATERIALS AND METHODS}

\subsection{Experimental diets}

One basal diet was formulated based on wheat, barley, oat, yeast and wheat bran (Tab. I) meeting Swiss nutrient requirements for finishing pigs [9]. The basal diet was then supplemented either with $2 \%$ lard (LA), linoleic- (SO) or conjugated linoleic acids (CLA) enriched oil. A commercial source of CLA (SELIN ${ }^{\mathrm{TM}}$ - CLA: Grünau Jllertissen $\mathrm{GmbH}$, Germany) was used to supplement the diet. The linoleic acid enriched oil is derived from sunflower oil and served as source material for the CLA production. Compared to the lard and the linoleic acidenriched oil, CLA was supplied in the form of free fatty acids. The diets were pelleted (4.5 mm diameters) at $60{ }^{\circ} \mathrm{C}$. During feed processing, feed samples were taken and bulked to determine nutrient content and lipid composition.

Table I. Ingredient composition (wt-\%) of the grower $\operatorname{diet}^{1}$.

\begin{tabular}{|c|c|c|c|}
\hline \multirow[b]{2}{*}{ Item } & \multicolumn{3}{|c|}{ Treatment } \\
\hline & CLA & $\mathrm{SO}$ & LA \\
\hline Wheat & 35.60 & 35.60 & 35.60 \\
\hline Barley & 29.00 & 29.00 & 29.00 \\
\hline Oat & 15.40 & 15.40 & 15.40 \\
\hline Yeast & 8.72 & 8.72 & 8.72 \\
\hline Wheat bran & 5.00 & 5.00 & 5.00 \\
\hline $\mathrm{NaCl}$ & 0.53 & 0.53 & 0.53 \\
\hline Dicalcium phosphate & 0.58 & 0.58 & 0.58 \\
\hline Limestone & 1.52 & 1.52 & 1.52 \\
\hline L-Lysin-HCl & 0.24 & 0.24 & 0.24 \\
\hline L-Threonine $98 \%$ & 0.05 & 0.05 & 0.05 \\
\hline Vitamin and mineral premix ${ }^{2}$ & 0.40 & 0.40 & 0.40 \\
\hline Pellan & 0.30 & 0.30 & 0.30 \\
\hline Color grit ${ }^{3}$ & 0.40 & 0.40 & 0.40 \\
\hline Conjugated linoleic acid (60\%) & 2.00 & & \\
\hline Linoleic acid & & 2.00 & \\
\hline Lard & & & 2.00 \\
\hline
\end{tabular}

${ }^{1}$ Grower diet was formulated to contain per kilogram of diet (as-fed basis) 13.1 MJ digestible energy, $150 \mathrm{~g}$ crude protein, $8.3 \mathrm{~g}$ lysine, $5.2 \mathrm{~g}$ methionine-cystine, $5.5 \mathrm{~g}$ threonine and $1.6 \mathrm{~g}$ tryptophan.

${ }^{2}$ Supplied the following nutrients per kilogram of diet: $20000 \mathrm{IU}$ vitamin $\mathrm{A}, 200 \mathrm{IU}$ vitamin $\mathrm{D}_{3}, 39 \mathrm{IU}$ vitamin $\mathrm{E}$, $2.9 \mathrm{mg}$ riboflavin, $2.4 \mathrm{mg}$ vitamin $\mathrm{B}_{6}, 0.010 \mathrm{mg}$ vitamin $\mathrm{B}_{12}, 0.2 \mathrm{mg}$ vitamin $\mathrm{K}_{3}, 10 \mathrm{mg}$ pantothenic acid, $1.4 \mathrm{mg}$ niacin, $0.48 \mathrm{mg}$ folic acid, $52 \mathrm{mg}$ Fe as Fe-sulfate, $0.16 \mathrm{mg} \mathrm{I}$ as $\mathrm{Ca}(\mathrm{IO})_{3}, 0.15 \mathrm{mg} \mathrm{Se}$ as Na $2 \mathrm{Se}, 5.5 \mathrm{mg} \mathrm{Cu}$ as $\mathrm{CuSO}_{4}$, $81 \mathrm{mg} \mathrm{Zn}$ as $\mathrm{ZnO}_{2}, 15 \mathrm{mg} \mathrm{Mn}$ as $\mathrm{MnO}_{2}, 199 \mathrm{~g}$ cholin, $0.052 \mathrm{mg}$ biotin.

${ }^{3}$ Color supplement added to the diets to avoid feeding mistakes. 


\subsection{Growth trial and carcass measurements}

The experiment involved 24 finishing pigs (Swiss Large White), 12 females and 12 barrows. From weaning until $25 \mathrm{~kg}$ of live weight, the pigs were group penned and fed a conventional starter diet ad libitum. At $25 \mathrm{~kg}$ live weight until slaughter the pigs were kept in individual pens on a solid concrete floor in an environmentally controlled building (temperature: $22{ }^{\circ} \mathrm{C}$, humidity: $60-70 \%$ ). All pigs had free access to a conventional grower diet prior to the start of the feeding trial.

At an average body weight of $70 \mathrm{~kg}$, the pigs were blocked by sex and then randomly assigned from within blocks to the three treatments (four animals from each sex). Pigs were fed two daily meals totaling $2.8 \mathrm{~kg}$ of the diet with free access to water. The animals were weighed weekly; eight days after they reached $98 \mathrm{~kg}$ live weight, they were slaughtered (average age: $163 \mathrm{~d}$ ) at the abattoir of the research station. Feed was withheld from animals $12 \mathrm{~h}$ before the pigs were brought to the abattoir, where they were electrically stunned and exsanguinated. Internal organs were removed and warm carcass weight was obtained. One day after slaughter the left side of each carcass was weighed and dissected according to meat cutting standards applied by the MLP (Swiss Pig Performance Testing Station, Sempach, Switzerland) [29]. Briefly, left carcass sides were separated into the major primal cuts (shoulder, loin, ham and belly). Shoulder, loin and ham were subsequently defatted and the total weight of the three cuts was expressed as a proportion of the cold left carcass side (lean percentage). Accordingly carcass fat percentage was calculated as the proportion of total weight of the dissected external fat from the loin, shoulder and ham to the cold left carcass side. Two cross sections of the longissimus dorsi (LD) muscle were removed at the 13 th rib for determination of the muscle area, color and drip loss. Drip loss was measured as the amount of purge resulting during the storage of the chop for $24 \mathrm{~h}$ at $2{ }^{\circ} \mathrm{C}$ [17]. Following a tenmin bloom, light reflectance coordinates ( $\mathrm{L}^{*}$ : brightness, $\mathrm{a}^{*}$ : red-green axis and $b^{*}$ : yellow-blue axis) of the muscle surface were measured using a Minolta Chroma Meter CR-300 with a $\mathrm{D}_{65}$ light source (Minolta, Dietikon, Switzerland).

\subsection{Sampling of tissues at slaughter and sample analysis}

At the day of slaughter, fat tissue samples from the back fat inner (BFI) and outer layer (BFO) in the region of the 13th and 14th dorsal vertebra and from the omental fat $(\mathrm{OF})$ were taken from the left side of the carcass, vacuumed and stored at $-20{ }^{\circ} \mathrm{C}$. Additionally, samples of LD muscle (14th vertebra) were collected, lyophilized, homogenized and stored at $-20^{\circ} \mathrm{C}$ until further analysis.

BFI, BFO, OF and LD muscles were analyzed for total lipid content by the method of Winter [40] and fatty acid methyl esters were prepared as reported earlier [2]. Briefly, $5 \mathrm{~g}$ of muscle or $300 \mathrm{mg}$ of adipose tissue were homogenized in $1 \mathrm{~mL}$ of triundecanine (11:0; internal standard) and $60 \mathrm{~mL}$ of dichloromethane/methanol (1:2, v/v) for $30 \mathrm{~s}$. After $15 \mathrm{~min}$, the filtered sample was added to $1 \mathrm{~mL} \mathrm{MgCl}_{2}\left(20 \mathrm{~g} \cdot \mathrm{L}^{-1}\right)$ and $20 \mathrm{~mL}$ water. The organic phase containing the lipid extract was removed and reduced in volume under vacuum $\left(550 \times 10^{2} \mathrm{~Pa}\right.$ at $40{ }^{\circ} \mathrm{C}$ ). The fatty acid methyl esters (FAME) were prepared by transesterification by methanolic sodium hydroxide and boron trifluoride according to the method of Metcalfe and Smith [23]. FAMEs were determined using a gas chromatograph (HP 5860 A GC, Hewlett-Packard, Urdorf, Switzerland), equipped with a flame ionization detector. The FAMEs were separated on a $30 \mathrm{~m} \times 0.32 \mathrm{~mm}$ Supelcowax ${ }^{\mathrm{TM}}$ 10 fused-silica capillary column (Supelco, Bellefonte, PA). The oven temperature was as follows: initial temperature $170{ }^{\circ} \mathrm{C}$ for 
$1 \mathrm{~min}$; raised to $250{ }^{\circ} \mathrm{C}$ with $2.5^{\circ} \mathrm{C} \cdot \mathrm{min}^{-1}$, $250{ }^{\circ} \mathrm{C}$ held for $7 \mathrm{~min}$. The detection temperature was at $250{ }^{\circ} \mathrm{C}$ and split at $250{ }^{\circ} \mathrm{C}$. FAMEs were quantified using 11:0 as the internal standard.

From the same lipid extract CLA-FAME were separated on the gas chromatograph mentioned above but using different oven temperatures (initial temperature $200^{\circ} \mathrm{C}$ for $15 \mathrm{~min}$; raised to $250^{\circ} \mathrm{C}$ with $20^{\circ} \mathrm{C} \cdot \mathrm{min}^{-1}$; $250{ }^{\circ} \mathrm{C}$ held for $10 \mathrm{~min}$; detection temperature was at $250{ }^{\circ} \mathrm{C}$ and split at $250^{\circ} \mathrm{C}$ ). CLA standards (Matreya, Inc, USA) were used to identify each CLA peak. A beef-pig fat blend reference standard (CRM 163: Commission of the European Communities, Community Bureau of Reference, Brussels, Belgium) was used to validate the measurements. The following CLA isomers were determined: cis9, trans11 $(\mathrm{c} 9, \mathrm{t} 11)-$, trans10, cis12 (t10,c12) - cis9, cis11 (c9,c11) and cis 10 , cis 12 (c10,c12). The trans 9 , trans11 $(\mathrm{t} 9, \mathrm{t} 11)$ and trans 10, trans $12(\mathrm{t} 10, \mathrm{t} 12)$ isomers could not be separated and are reported as the sum of both isomers $(\mathrm{t} 9, \mathrm{t} 11)$ $\mathrm{t} 10, \mathrm{t} 12)$.

\subsection{Enzyme activities}

At the abattoir, weighted quantities of BFO, BFI and OF were homogenized in an ice cooled homogenization buffer $(0.25 \mathrm{M}$ sucrose; $0.1 \mathrm{M}$ potassium phosphate, $1 \mathrm{mM}$ EDTA, 0.05 M $\beta$-mercaptoethanol). The samples were centrifuged twice at $15000 \mathrm{~g}$ for $10 \mathrm{~min}$ and the supernatant was recentrifuged at $30000 \mathrm{~g}$ for $40 \mathrm{~min}$ in the same buffer. The supernatants were stored at $-70{ }^{\circ} \mathrm{C}$ to assess lipogenic enzyme activities using standard photometric methods. The day after collection samples were analyzed in duplicate for malic enzyme (ME, EC 1.1.1.40) and fatty acid synthase (FAS, EC 2.3.1.85) using the methods of Hsu and Lardy [18] and Roncari [30], respectively. NADPH formation (ME) or oxidation (FAS) was measured at $37^{\circ} \mathrm{C}$ by absorbance at $340 \mathrm{~nm}$. A commercial protein dye-binding assay kit, using bovine gamma globulin as a standard, was used to measure the soluble protein concentration in the supernatant fraction (Bio-Rad Protein Assay, Bio-Rad, Switzerland). The enzyme activities were expressed as $\mu$ mol NADPH produced or oxidized $\cdot \mathrm{min}^{-1} \cdot \mathrm{mg}^{-1}$ protein.

\subsection{Statistical analysis}

Performance, carcass evaluation, carcass fat and meat lipid and lipogenic enzyme activity data were analyzed with the PROC GLM procedure of SAS [31]. Treatment, sex and treatment $\times$ sex interaction were included as fixed factors in the model. The individual pig values were considered as the experimental unit for all response parameters. For the carcass evaluation data, hot carcass weight was included as a covariate in the model. Multiple comparison of means were carried out with the Bonferroni test and differences with probability levels of $P<0.05$ were considered significant. No significant treatment $\times$ sex interactions were found, therefore only main effect treatment means are reported in the tables and significant sex effects were indexed.

\section{RESULTS AND DISCUSSION}

\subsection{Diet}

The oil added to the SO finisher diet was mainly composed of linoleic [18:2(n-6): $65.8 \mathrm{~g} \cdot 100 \mathrm{~g}^{-1}$ total fatty acids] and oleic acid [18:1(n-9): $23.9 \mathrm{~g} \cdot 100 \mathrm{~g}^{-1}$ total fatty acids]. By contrast, in the lard the predominant fatty acid was oleic acid and in decreasing order palmitic [16:0], stearic [18:0] and linoleic acid. The most abundant CLA isomer found in the CLA-enriched oil $(58.9 \mathrm{~g}$ CLA isomers $\cdot 100 \mathrm{~g}^{-1}$ of total fatty acids) was t10,c12; other CLA in decreasing order were $\mathrm{c} 9, \mathrm{t} 11>\mathrm{t} 9, \mathrm{t} 11 / \mathrm{t} 10, \mathrm{t} 12>\mathrm{c} 9, \mathrm{c} 11>$ $\mathrm{c} 10, \mathrm{c} 12$. The other main fatty acid of the CLA oil was oleic acid, whereas saturated and other unsaturated fatty acids were 
present only at low levels. The fatty acid profile of the dietary lipid reflected the fat supplementation (Tab. II). Compared to the LA diet, the CLA and SO diets were lower in palmitic, stearic, total SFA and higher in palmitoleic [16:1(n-7)], oleic, linoleic and total MUFA. The CLA and LA diets had similar contents of linoleic acid, but the level was almost two times greater in the SO diet. However, total PUFA content was not

Table II. Lipid content and fatty acid composition of the grower diets ${ }^{1}$.

\begin{tabular}{|c|c|c|c|}
\hline \multirow[b]{2}{*}{ Item } & \multicolumn{3}{|c|}{ Treatment } \\
\hline & CLA & $\mathrm{SO}$ & LA \\
\hline Lipid $\left[\mathrm{g} \cdot \mathrm{kg}^{-1}\right]$ & 43.73 & 43.32 & 43.12 \\
\hline \multicolumn{4}{|c|}{ Fatty acids $\left[\mathrm{g} \cdot 100 \mathrm{~g}^{-1} \text { total fatty acids }\right]^{2}$} \\
\hline 14:0 (myristic) & 0.13 & $\mathrm{ND}^{3}$ & 0.96 \\
\hline 16:0 (palmitic) & 11.78 & 12.66 & 21.33 \\
\hline 18:0 (stearic) & 1.49 & 2.42 & 7.65 \\
\hline 22:0 (behenic) & 0.24 & 0.40 & ND \\
\hline SFA & 13.64 & 15.47 & 30.23 \\
\hline 16:1(n-7) (palmitoleic) & 1.30 & 1.27 & 2.45 \\
\hline 18:1(n-9) (oleic) & 25.54 & 23.27 & 31.87 \\
\hline 20:1(n-9) (eicosenoic) & 0.48 & 0.46 & 0.78 \\
\hline MUFA & 27.49 & 25.19 & 35.60 \\
\hline 18:2(n-6) (linoleic) & 29.46 & 56.88 & 31.74 \\
\hline $\mathrm{CLA}^{4}$ & 24.26 & ND & ND \\
\hline 18:3(n-3) ( $\alpha$-linolenic) & 2.19 & 2.46 & 2.44 \\
\hline PUFA & 58.87 & 59.33 & 34.17 \\
\hline $16: 1(n-7) / 16: 0$ & 0.11 & 0.10 & 0.11 \\
\hline $18: 1(n-9) / 18: 0$ & 17.11 & 9.63 & 4.16 \\
\hline \multicolumn{4}{|l|}{ CLA isomer $^{5,6}$} \\
\hline $\mathrm{c} 9, \mathrm{t} 11$ & \multicolumn{3}{|c|}{$10.13(41.8 \%)$} \\
\hline $\mathrm{c} 9, \mathrm{c} 11$ & \multicolumn{3}{|c|}{$1.77(7.3 \%)$} \\
\hline $\mathrm{t} 10, \mathrm{c} 12$ & \multicolumn{3}{|c|}{$10.75(44.3 \%)$} \\
\hline $\mathrm{c} 10, \mathrm{c} 12$ & \multicolumn{3}{|c|}{$0.65(2.7 \%)$} \\
\hline $\mathrm{t} 9, \mathrm{t} 11 / \mathrm{t} 10, \mathrm{t} 12$ & \multicolumn{3}{|c|}{$3.91(16.1 \%)$} \\
\hline
\end{tabular}

${ }^{1}$ Only fatty acids that accounted for $\geq 0.1$ weight percentages of total are presented.

${ }^{2}$ Fatty acids are designated by the number of carbon atoms followed by the number of double bonds. The position of the first double-bond relative to the methyl $(n)$ end of the molecule is also indicated. The sums of the main fatty acid series are represented as: SFA = saturated fatty acids, MUFA = monounsaturated fatty acids, PUFA = polyunsaturated fatty acids. Values are expressed as weight percentages of total fatty acids.

${ }^{3} \mathrm{ND}$, not detected.

${ }^{4}$ Sum of the $\mathrm{c} 9, \mathrm{t} 11 ; \mathrm{c} 9, \mathrm{c} 11 ; \mathrm{t} 10, \mathrm{c} 12 ; \mathrm{c} 10, \mathrm{c} 12$ and $\mathrm{t} 9, \mathrm{t} 11 / \mathrm{t} 10, \mathrm{t} 12$ CLA isomers.

${ }^{5} \mathrm{c}=\mathrm{cis} ; \mathrm{t}=$ trans.

${ }^{6}$ Amount of CLA isomers $\left(\mathrm{g} \cdot 100 \mathrm{~g}^{-1}\right)$ in the total fatty acid methyl ester and in round brackets the relative composition $(\%)$ in the total CLA. 
different between the CLA and LA diets. None of the determined CLA isomers were detected in the SO and LA diets.

\subsection{Growth performance, carcass characteristics and morphometric muscle measurements}

Growth performance and carcass characteristics were not affected by neither the sex nor the diet, except for the loin fat depth which was decreased in the CLA compared to the SO group (Tab. III). The lack of difference between the SO and LA treatment was not surprising, because both diets had equal calculated digestible energy contents and contained only $2 \%$ fat. Likewise, we previously reported that feeding diets varying in the fatty acid composition but with a moderated fat level did not affect production and carcass traits $[4,6]$. In agreement with other studies $[14,27]$, CLA had no effect on daily weight gain. However, in those experiments, where animals had free access to the feed, CLA inclusion significantly reduced feed intake [14] and improved the feed conversion ratio [14, 27]. By contrast, in the present experiment all animals were fed daily a fixed amount of feed $\left(2.8 \mathrm{~kg} \cdot \mathrm{d}^{-1}\right)$. If feed intake is set below that which the animal freely chooses in an ad libitum situation, then improvements in feed conversion should be reflected in an

Table III. Growth performance, carcass measurements and morphometric muscle measurements ${ }^{1}$.

\begin{tabular}{|c|c|c|c|c|}
\hline \multirow[b]{2}{*}{ Item } & \multicolumn{4}{|c|}{ Treatment $^{2}$} \\
\hline & CLA & SO & LA & SEM \\
\hline \multicolumn{5}{|l|}{ Growth performance } \\
\hline Initial live weight (kg) & 70.7 & 72.2 & 69.7 & 0.7 \\
\hline Final live weight (kg) & 105.4 & 106.2 & 104.6 & 0.8 \\
\hline Weight gain $\left(\mathrm{kg} \cdot \mathrm{d}^{-1}\right)$ & 1.00 & 0.95 & 0.93 & 0.03 \\
\hline $\mathrm{FCR}^{3}\left(\mathrm{~kg} \cdot \mathrm{kg}^{-1}\right)$ & 2.81 & 2.95 & 3.00 & 0.10 \\
\hline \multicolumn{5}{|l|}{ Carcass measurements } \\
\hline Hot carcass weight (kg) & 85.9 & 86.7 & 86.1 & 0.8 \\
\hline Lean percentage ${ }^{4}(\%)$ & 56.6 & 57.7 & 56.8 & 0.9 \\
\hline Carcass fat percentage ${ }^{5}(\%)$ & 12.6 & 13.6 & 13.0 & 0.4 \\
\hline LD fat depth (mm) & $13.8^{\mathrm{a}}$ & $18.5^{\mathrm{b}}$ & $17.4^{\mathrm{b}}$ & 0.9 \\
\hline Rump fat depth (mm) & 16.1 & 16.6 & 17.2 & 0.9 \\
\hline \multicolumn{5}{|l|}{ Longissimus dorsi measurements } \\
\hline LD muscle area $\left(\mathrm{cm}^{2}\right)$ & 65.6 & 67.7 & 64.7 & 2.3 \\
\hline $\mathrm{L}^{*}$ & $49.8^{\mathrm{ab}}$ & $50.5^{\mathrm{a}}$ & $48.9^{\mathrm{b}}$ & 0.4 \\
\hline$a^{*}$ & 7.3 & 6.8 & 7.4 & 0.4 \\
\hline$b^{*}$ & 4.6 & 4.2 & 4.7 & 0.4 \\
\hline Drip loss $\left(\mathrm{g} \cdot 100 \mathrm{~g}^{-1}\right)$ & 4.0 & 4.8 & 3.7 & 0.6 \\
\hline
\end{tabular}

${ }^{1}$ Results are presented as least-square means $(n=8)$ and standard error of the mean (SEM).

2 a,b,c Least-square means within a row not sharing a common superscript differ $(P<0.05)$.

${ }^{3} \mathrm{FCR}$, feed conversion ratio $=\mathrm{kg}$ food intake per $\mathrm{kg}$ weight gain.

${ }^{4}$ Lean percentage: total weight of defatted loin, shoulder and ham expressed as a percentage of the cold left carcass side.

${ }^{5}$ Carcass fat percentage: total weight of external fat from the loin, shoulder and ham expressed as a percentage of the cold left carcass side. 
increased growth rate. While daily weight gain was increased 5-7\% in the CLA-fed pigs, this increase was not significant. Besides the feeding strategy, the length of CLA feeding might be a determinant factor for improved growth performance. Thiel et al. [36] reported a linear increase in growth rate and gain:feed ratio, when pigs were fed CLA supplemented diets from initial body weight of 26 to $116 \mathrm{~kg}$ body weight at slaughter. Sparks et al. [34] showed a maximum response to CLA concerning gain: feed ratios if fed during the last $58 \mathrm{~kg}$ of body weight gain. Gilts and barrows had similar average daily weight gain (gilts: 0.97 vs. barrows: $0.95 \mathrm{~kg} \cdot \mathrm{d}^{-1} ; P=0.59$ ) and feed conversion ratios (gilts: 2.88 vs. barrows: $\left.2.96 \mathrm{~kg} \cdot \mathrm{kg}^{-1} ; P=0.50\right)$.

In agreement with recent studies [16, 34], we report decreased loin fat depth in the CLA group. However, neither rump fat thickness nor carcass fat percentage was lower nor was lean percentage higher compared to the SO and LA group. The latter is in contrast to the results reported by Ostrowska et al. [27] showing a dose dependent decrease in carcass fat deposition up to $31 \%$ due to CLA feeding. Compared to the pigs used in the latter study, those used in the present experiment were already lean. Ostrowska et al. [27] reported for their animals in the control group (diet supplemented with $2 \%$ soybean oil) $\mathrm{P}_{2}$ backfat thickness of $24 \mathrm{~mm}$, which was $\sim 33 \%$ higher then that measured in the pigs of the SO group in the present study. This difference might explain the lack of conformity of results, although the direction of response was as anticipated and consistent with the before-mentioned studies. LD muscle color characteristics did not differ between the treatments, except for the $\mathrm{L}^{*}$ value (lightness) that was higher in the LA treatment compared to the SO group. The lack of CLA effect on LD muscle area, meat color and drip loss confirm results of earlier studies [13, 15, 16]. As expected, gilts tended to be leaner (58.0 vs. $56.1 \%$ lean, $P=0.06 ; 12.6$ vs. $13.5 \%$ fat, $P=0.07)$ than barrows.

\subsection{Lipogenic enzyme activity, lipid content and fatty acid profile of the fat tissues}

In pigs weighing more than $80 \mathrm{~kg}, \mathrm{ME}$ becomes the main producer of NADPH for the reductive biosynthesis of fatty acids and has been suggested to be the rate limiting enzyme in the lipogenic process [25]. The activity level of ME within treatments was higher in the OF than in the backfat layers, but within fat tissues no effect of the dietary fats were detected (Tab. IV). Considering the ME activity as a good indicator of lipogenesis [22], the lack of effect of the supplemented dietary fats on ME activity confirms the results of the carcass fat percentage.

FAS regulates the final step in the de novo biosynthetic pathway. Fatty acids of the (n-6) and (n-3) family are reported to be potent inhibitors of FAS activity in rodents [8]. By contrast, Smith et al. [33] reported that palmitic acid was more potent in inhibiting lipogenesis (measured as glucose incorporation into lipids). Although dietary intake of those fatty acids differed between the treatment groups, the activity level of FAS was not influenced. Furthermore dietary CLA did not affect the activity level of FAS, which confirms previous results reported in piglets [3] and rats [1].

Independent of the dietary fats, the degree of saturation was lowest in the BFO (Tab. V), intermediate in the BFI (Tab. VI) and highest in the OF (Tab. VII), mainly as the result of differences in the contents of palmitic, stearic, palmitoleic and oleic acid. The differences in the PUFA levels between tissues were less pronounced. Total lipid content as well as the level of heptadecanoic (17:0) and palmitoleic acid was not affected by dietary fat supplementation. However, compared to SO or LA, the inclusion of CLA markedly increased the myristic (14:0), palmitic, behenic (20:0) and total SFA content in the three fat tissues $(P<0.05)$. Stearic acid was increased by the CLA treatment in the BFI and, compared to the LA group, 
Table IV. In vitro lipogenic enzyme activity in fat tissues ${ }^{1}$ as affected by dietary fatty acids ${ }^{2}$.

\begin{tabular}{lrrrr}
\hline & \multicolumn{4}{c}{ Treatment $^{3}$} \\
\cline { 2 - 5 } Item & CLA & SO & LA & SEM \\
\hline ME $^{4}$ & & & & \\
BFO & $103.1^{\mathrm{x}}$ & $104.4^{\mathrm{x}}$ & $93.7^{\mathrm{x}}$ & 8.2 \\
BFI & $97.8^{\mathrm{x}}$ & $109.3^{\mathrm{x}}$ & $104.9^{\mathrm{x}}$ & 8.2 \\
OF & $132.6^{\mathrm{y}}$ & $141.2^{\mathrm{y}}$ & $123.6^{\mathrm{y}}$ & 8.2 \\
FAS $^{5}$ & & & & \\
BFO & 4.4 & 4.9 & 4.6 & 0.3 \\
BFI & 5.0 & 4.9 & 5.3 & 0.3 \\
OF & 5.2 & 5.1 & 5.5 & 0.3 \\
\hline
\end{tabular}

${ }^{1}$ BFO: back fat outer layer; BFI: back fat inner layer; OF: omental fat.

${ }^{2}$ Results are presented as least-square means $(n=8)$ and standard error of the mean (SEM).

$3 \mathrm{x}, \mathrm{y}$ Least-square means within a column not sharing a common superscript differ $(P<0.05)$.

${ }^{4} \mathrm{ME}$ (malic enzyme, EC 1.1.1.40) activities are expressed in $\mu \mathrm{mol}$ NADPH produced $\cdot \mathrm{min}^{-1} \cdot \mathrm{mg}^{-1}$ protein.

${ }^{5}$ FAS (fatty acid synthase, EC 2.3 .1 .85 ) activities are expressed in $\mu \mathrm{mol}$ NADPH oxidized $\cdot \mathrm{min}^{-1} \cdot \mathrm{mg}^{-1}$ protein.

also in the BFO $(P<0.05$ for each), but not in the OF. By contrast, there was no difference in the distribution pattern of the saturated fatty acids between the LA and $\mathrm{SO}$ group. Oleic, eicosenoic [20:1(n-7)] and total MUFA contents were the highest in the fat tissues of animals fed the LA diet and were the lowest in those fed CLA. In both back fat layers, SFA level was higher and MUFA level was lower in the barrows than in the gilts, whereas PUFA concentration was not different. In the OF, these differences were less evident.

The SFA and MUFA concentrations of the backfat layers and OF did not reflect the supply, because the intake of saturated fatty acids, mainly palmitic and stearic acid, was similar for the CLA and SO group, but almost half that of the LA group. By contrast the tissue concentrations were similar between the SO and LA group, but were significantly increased in the CLA group. The level of palmitic and stearic acid of plant oil based diets is mainly dictated by the de novo fatty acid synthesis, whereas dietary supply only has a minimal effect
[24]. By contrast, the level of oleic acid, the main MUFA in swine adipose tissue, is determined by the dietary supply and by the desaturation of stearic acid. PUFA of the n6 and n-3 family are known to affect gene transcription $[11,12,26]$ as well as the activity level of stearoyl-CoA desaturase [10, 19, 20]. Based on data of other research [4], we anticipated that MUFA, especially oleic acid deposition would be lower in animals fed diets containing rather high amounts of PUFA (CLA, SO) [5, 6]. However, the observation that the fatty acid pattern of the adipose tissues were different for the CLA and SO groups was unexpected because total dietary PUFA and total dienoic acid levels were similar. Independent of the fat tissues, the desaturation index expressed as the ratio of palmitoleic to palmitic acid [16:1(n-7)/16:0] and oleic to stearic acid [18:1(n-9)/18:0] was the lowest in the CLA and the highest in the LA group, whereas that of the SO group was intermediate. By contrast the dietary oleic to stearic acid ratio was the highest in the LA diet and the lowest in the CLA diet and the palmitoleic to palmitic acid ratio was similar for the three diets. 
Compared to the CLA and LA diet, feeding the SO diet increased $(P<0.05)$ the levels of linoleic acid and eicosadienoic acid [20:2(n-6)] in all three fat tissues. Arachidonic acid [20:4(n-6)] content of the BFI and $\mathrm{OF}$ were markedly decreased $(P<0.05)$ in the CLA group. The linolenic acid [18:3(n-3)] level was not affected by the dietary fats and that of eicosatrienoic [20:3(n-3)] was decreased $(P<0.05)$ in the OF of the CLA group but not in the backfat layers. Overall total PUFA concentration was the highest in the SO group and the lowest in the LA group. Compared to the SO group, PUFA level was decreased $(P<0.05)$ in the OF of the CLA group but

Table V. Fat content and fatty acid profile of the back fat outer layer as affected by dietary fatty acids ${ }^{1}$.

\begin{tabular}{|c|c|c|c|c|}
\hline \multirow[b]{2}{*}{ Item } & \multicolumn{4}{|c|}{ Treatment $^{2}$} \\
\hline & CLA & $\mathrm{SO}$ & LA & SEM \\
\hline Lipid $\left(\mathrm{g} \cdot 100 \mathrm{~g}^{-1}\right)$ & 86.6 & 87.9 & 87.9 & 1.53 \\
\hline \multicolumn{5}{|c|}{ Fatty acid $\left(\mathrm{g} \cdot 100 \mathrm{~g}^{-1} \text { total fatty acids }\right)^{3}$} \\
\hline $14: 0$ & $2.04^{\mathrm{b}}$ & $1.52^{\mathrm{a}}$ & $1.48^{\mathrm{a}}$ & 0.05 \\
\hline $16: 0$ & $26.29^{\mathrm{b}}$ & $24.34^{\mathrm{a}}$ & $24.44^{\mathrm{a}}$ & 0.38 \\
\hline 17:0 & 0.38 & 0.35 & 0.34 & 0.02 \\
\hline 18:0 & $15.47^{\mathrm{b}}$ & $13.96^{\mathrm{ab}}$ & $13.34^{\mathrm{a}}$ & 0.48 \\
\hline 20:0 & $0.14^{\mathrm{a}}$ & $0.17^{\mathrm{b}}$ & $0.18^{\mathrm{b}}$ & 0.01 \\
\hline $\mathrm{SFA}^{4}$ & $44.61^{\mathrm{b}}$ & $40.57^{\mathrm{a}}$ & $39.98^{\mathrm{a}}$ & 0.76 \\
\hline $16: 1(n-7)$ & 2.44 & 2.36 & 2.72 & 0.12 \\
\hline $18: 1(n-9)$ & $34.29^{\mathrm{a}}$ & $37.48^{\mathrm{b}}$ & $41.89^{c}$ & 0.54 \\
\hline $20: 1(n-9)$ & $0.58^{\mathrm{a}}$ & $0.78^{\mathrm{b}}$ & $0.91^{\mathrm{b}}$ & 0.04 \\
\hline MUFA $^{5}$ & $37.69^{\mathrm{a}}$ & $41.00^{\mathrm{b}}$ & $45.94^{c}$ & 0.56 \\
\hline $18: 2(n-6)$ & $11.94^{\mathrm{a}}$ & $15.78^{\mathrm{b}}$ & $11.73^{\mathrm{a}}$ & 0.44 \\
\hline $\mathrm{CLA}^{6}$ & 4.15 & traces $^{6}$ & traces & 0.10 \\
\hline $20: 2(n-6)$ & $0.40^{\mathrm{a}}$ & $0.64^{\mathrm{b}}$ & $0.48^{\mathrm{a}}$ & 0.02 \\
\hline $20: 4(n-6)$ & $0.20^{\mathrm{b}}$ & $0.26^{\mathrm{b}}$ & $0.25^{\mathrm{ab}}$ & 0.01 \\
\hline $18: 3(n-3)$ & 0.86 & 0.86 & 0.85 & 0.02 \\
\hline $20: 3(n-3)$ & 0.13 & 0.14 & 0.14 & 0.01 \\
\hline PUFA & $17.70^{\mathrm{b}}$ & $18.43^{b}$ & $14.08^{\mathrm{a}}$ & 0.52 \\
\hline $16: 1(n-7) / 16: 0$ & $0.09^{\mathrm{a}}$ & $0.10^{\mathrm{ab}}$ & $0.11^{\mathrm{b}}$ & 0.01 \\
\hline $18: 1(n-9) / 18: 0$ & $2.23^{\mathrm{a}}$ & $2.72^{\mathrm{b}}$ & $3.17^{\mathrm{c}}$ & 0.12 \\
\hline
\end{tabular}

${ }^{1}$ Results are presented as least-square means $(n=8)$ and standard error of the mean (SEM).

2 a,b,c Least-square means within a row not sharing a common superscript differ $(P<0.05)$.

${ }^{3}$ Fatty acids are designated by the number of carbon atoms followed by the number of double bonds. The position of the first double-bond relative to the methyl $(n)$ end of the molecule is also indicated. The sums of the main fatty acid series are represented as: SFA $=$ saturated fatty acids, MUFA $=$ monounsaturated fatty acids, PUFA $=$ polyunsaturated fatty acids

${ }^{4}$ Gender effect is significant $(P<0.05)$.

${ }^{5}$ Sum of $\mathrm{c} 9, \mathrm{t} 11 ; \mathrm{c} 9, \mathrm{c} 11 ; \mathrm{t} 10, \mathrm{t} 12 ; \mathrm{c} 10, \mathrm{c} 12$ and $\mathrm{t} 9, \mathrm{t} 11 / \mathrm{t} 10, \mathrm{t} 12$ 18:2 isomers.

${ }^{6}$ Traces: less than $0.1 \mathrm{~g} \cdot 100 \mathrm{~g}^{-1}$ total fatty acids. 
not in the BFO and BFI. The observation that linoleic, linolenic and arachidonic acid levels of adipose tissue reflect dietary supply is well documented [24, 38, 39]. However the present effect on the arachidonic acid level, the main derivative of linoleic acid, which was not detected in the three diets, was not anticipated. The question arises, if the lower arachidonic acid level in the tissues of the CLA group was due to the lower dietary supply of the substrate or to the inhibition of one or both of the specific desaturases ( $\Delta 6-, \Delta 5$-desaturase). It is unlikely that differences in the uptake of the substrate might have been the reason for the differences in the deposition of arachidonic

Table VI. Fat content and fatty acid profile of the back fat inner layer as affected by dietary fatty acids ${ }^{1}$.

\begin{tabular}{|c|c|c|c|c|}
\hline \multirow[b]{2}{*}{ Item } & \multicolumn{4}{|c|}{ Treatment $^{2}$} \\
\hline & CLA & $\mathrm{SO}$ & LA & SEM \\
\hline Lipid $\left(g \cdot 100 g^{-1}\right)$ & 84.3 & 87.5 & 87.2 & 1.57 \\
\hline \multicolumn{5}{|c|}{ Fatty acid $\left(\mathrm{g} \cdot 100 \mathrm{~g}^{-1} \text { total fatty acids }\right)^{3}$} \\
\hline $14: 0$ & $2.05^{\mathrm{b}}$ & $1.43^{\mathrm{a}}$ & $1.39^{\mathrm{a}}$ & 0.05 \\
\hline $16: 0$ & $27.98^{\mathrm{b}}$ & $25.18^{\mathrm{a}}$ & $25.40^{\mathrm{a}}$ & 0.37 \\
\hline $17: 0$ & 0.33 & 0.30 & 0.29 & 0.02 \\
\hline $18: 0^{4}$ & $17.98^{\mathrm{b}}$ & $15.86^{\mathrm{a}}$ & $15.46^{\mathrm{a}}$ & 0.49 \\
\hline 20:0 & $0.15^{\mathrm{b}}$ & $0.19^{\mathrm{a}}$ & $0.20^{\mathrm{a}}$ & 0.01 \\
\hline $\mathrm{SFA}^{4}$ & $48.77^{\mathrm{a}}$ & $43.17^{b}$ & $42.92^{\mathrm{b}}$ & 0.74 \\
\hline $16: 1(n-7)$ & 2.17 & 2.11 & 2.39 & 0.10 \\
\hline $18: 1(n-9)$ & $31.24^{\mathrm{a}}$ & $35.93^{\mathrm{b}}$ & $40.81^{\mathrm{c}}$ & 0.54 \\
\hline $20: 1(n-9)$ & $0.61^{\mathrm{a}}$ & $0.83^{\mathrm{b}}$ & $1.01^{\mathrm{c}}$ & 0.05 \\
\hline MUFA $^{4}$ & $34.30^{\mathrm{a}}$ & $39.18^{b}$ & $44.55^{\mathrm{c}}$ & 0.56 \\
\hline $18: 2(n-6)$ & $10.75^{\mathrm{a}}$ & $15.23^{\mathrm{b}}$ & $10.52^{\mathrm{a}}$ & 0.41 \\
\hline $\mathrm{CLA}^{5}$ & 4.79 & traces $^{6}$ & traces & 0.12 \\
\hline $20: 2(n-6)$ & $0.41^{\mathrm{a}}$ & $0.68^{\mathrm{b}}$ & $0.48^{\mathrm{a}}$ & 0.03 \\
\hline $20: 4(n-6)$ & $0.15^{\mathrm{a}}$ & $0.22^{\mathrm{b}}$ & $0.20^{\mathrm{b}}$ & 0.01 \\
\hline $18: 3(n-3)$ & 0.73 & 0.76 & 0.72 & 0.03 \\
\hline $20: 3(n-3)$ & 0.11 & 0.12 & 0.12 & 0.01 \\
\hline PUFA & $16.93^{b}$ & $17.65^{\mathrm{b}}$ & $12.53^{\mathrm{a}}$ & 0.49 \\
\hline $16: 1(n-7) / 16: 0$ & $0.08^{\mathrm{a}}$ & $0.08^{\mathrm{ab}}$ & $0.09^{\mathrm{b}}$ & $<0.01$ \\
\hline $18: 1(n-9) / 18: 0^{4}$ & $1.74^{\mathrm{a}}$ & $2.30^{\mathrm{b}}$ & $2.67^{\mathrm{c}}$ & 0.09 \\
\hline
\end{tabular}

${ }^{1}$ Results are presented as least-square means $(n=8)$ and standard error of the mean (SEM).

2 a,b,c Least-square means within a row not sharing a common superscript differ $(P<0.05)$.

${ }^{3}$ Fatty acids are designated by the number of carbon atoms followed by the number of double bonds. The position of the first double-bond relative to the methyl $(n)$ end of the molecule is also indicated. The sums of the main fatty acid series are represented as: SFA = saturated fatty acids, MUFA = monounsaturated fatty acids, PUFA $=$ polyunsaturated fatty acids

${ }^{4}$ Gender effect is significant $(P<0.05)$.

5 Sum of c9,t11; c9,c11; t10,t12; c10,c12 and t9,t11/t10,t12 18:2 isomers.

${ }^{6}$ Traces: less than $0.1 \mathrm{~g} \cdot 100 \mathrm{~g}^{-1}$ total fatty acids. 
acid, because dietary supply of linoleic acid was only slightly lower in the CLA group (29.46\% compared to the $31.74 \%$ in the LA group), but total supply of 18:2 isomers of the CLA group was almost two-fold those in the LA group $(29.46 \% 18: 2(n-6)$ plus $24.26 \%$ CLA). Belury and Kempa-Steczko [7] suggested that CLA may compete with linoleic acid for the $\Delta 6$-desaturase, since radiolabeled CLA was desaturated to a similar extent as radiolabeled linoleic acid. Decreased elongation and desaturation could explain why the level of linoleic acid was similar whereas that of arachidonic acid was lower in the CLA group compared to the LA group.

Table VII. Fat content and fatty acid profile of the omental fat as affected by dietary fatty acids ${ }^{1}$.

\begin{tabular}{|c|c|c|c|c|}
\hline \multirow[b]{2}{*}{ Item } & \multicolumn{4}{|c|}{ Treatment $^{2}$} \\
\hline & CLA & $\mathrm{SO}$ & LA & SEM \\
\hline Lipid $\left(g \cdot 100 g^{-1}\right)$ & 84.6 & 87.9 & 85.1 & 3.17 \\
\hline \multicolumn{5}{|c|}{ Fatty acid $\left(\mathrm{g} \cdot 100 \mathrm{~g}^{-1} \text { total fatty acids }\right)^{3}$} \\
\hline $14: 0$ & $2.39^{b}$ & $1.62^{\mathrm{a}}$ & $1.59^{\mathrm{a}}$ & 0.05 \\
\hline $16: 0$ & $32.06^{\mathrm{b}}$ & $27.80^{\mathrm{a}}$ & $28.13^{\mathrm{a}}$ & 0.36 \\
\hline $17: 0$ & 0.30 & 0.30 & 0.31 & 0.02 \\
\hline 18:0 & 20.43 & 19.24 & 19.25 & 0.59 \\
\hline $20: 0^{4}$ & $0.14^{\mathrm{a}}$ & $0.20^{\mathrm{b}}$ & $0.20^{\mathrm{b}}$ & 0.01 \\
\hline SFA & $55.89^{b}$ & $49.43^{\mathrm{a}}$ & $49.71^{\mathrm{a}}$ & 0.82 \\
\hline $16: 1(n-7)$ & 2.06 & 1.86 & 2.12 & 0.10 \\
\hline $18: 1(n-9)$ & $26.06^{\mathrm{a}}$ & $30.75^{b}$ & $34.90^{\mathrm{c}}$ & 0.48 \\
\hline $20: 1(n-9)$ & $0.43^{\mathrm{a}}$ & $0.65^{b}$ & $0.74^{\mathrm{b}}$ & 0.04 \\
\hline MUFA & $28.78^{a}$ & $33.52^{b}$ & $38.07^{\mathrm{c}}$ & 0.53 \\
\hline $18: 2(n-6)$ & $9.75^{\mathrm{a}}$ & $14.96^{\mathrm{b}}$ & $10.34^{\mathrm{a}}$ & 0.46 \\
\hline $\mathrm{CLA}^{5}$ & 4.65 & $\operatorname{traces}^{6}$ & traces & 0.10 \\
\hline $20: 2(n-6)$ & $0.29^{\mathrm{a}}$ & $0.52^{\mathrm{c}}$ & $0.38^{\mathrm{b}}$ & 0.02 \\
\hline $20: 4(n-6)$ & $0.15^{\mathrm{a}}$ & $0.23^{b}$ & $0.22^{\mathrm{b}}$ & 0.01 \\
\hline $18: 3(n-3)^{4}$ & 0.68 & 0.75 & 0.74 & 0.03 \\
\hline $20: 3(n-3)$ & $0.06^{\mathrm{a}}$ & $0.09^{b}$ & $0.09^{\mathrm{b}}$ & 0.01 \\
\hline PUFA & $15.58^{b}$ & $17.05^{\mathrm{c}}$ & $12.23^{\mathrm{a}}$ & 0.42 \\
\hline $16: 1(n-7) / 16: 0$ & 0.06 & 0.07 & 0.08 & $<0.01$ \\
\hline $18: 1(n-9) / 18: 0$ & $1.28^{\mathrm{a}}$ & $1.62^{b}$ & $1.83^{b}$ & 0.07 \\
\hline
\end{tabular}

${ }^{1}$ Results are presented as least-square means $(n=8)$ and standard error of the mean (SEM).

2 a,b,c Least-square means within a row not sharing a common superscript differ $(P<0.05)$.

${ }^{3}$ Fatty acids are designated by the number of carbon atoms followed by the number of double bonds. The position of the first double-bond relative to the methyl $(n)$ end of the molecule is also indicated. The sums of the main fatty acid series are represented as: SFA = saturated fatty acids, MUFA = monounsaturated fatty acids, PUFA $=$ polyunsaturated fatty acids

${ }^{4}$ Gender effect is significant $(P<0.05)$.

${ }^{5}$ Sum of c9,t11; c9,c11; t10,t12; c10,c12 and t9,t11/t10,t12 18:2 isomers.

${ }^{6}$ Traces: less than $0.1 \mathrm{~g} \cdot 100 \mathrm{~g}^{-1}$ total fatty acids. 
Total CLA concentrations of the treatment groups were similar in the BFO (Tab. V), BFI (Tab. VI) and OF (Tab. VII). The most abundant isomer, independent of the fat tissues, was c9,t11 and in decreasing order $\mathrm{t} 10, \mathrm{c} 12>\mathrm{t} 9, \mathrm{t} 11 / \mathrm{t} 10, \mathrm{t} 11>\mathrm{c} 9, \mathrm{c} 11>\mathrm{c} 10, \mathrm{c} 12$. Total CLA concentration as well as the distribution of the CLA isomers in the fat tissues was not different between sexes.

At least for the two main isomers (c9,c11; $\mathrm{t} 10, \mathrm{c} 12)$ the tissue concentration did not reflect the supply, since the CLA diet contained slightly higher amounts of t10,c12 (Tab. II). Differences in the absorption rate of the different isomers could be one of the reasons for the differences between uptake and incorporation. From the results of a study with sows fed a CLA enriched diet during pregnancy, we estimated that the transfer efficiency (intake to deposition into the backfat) was about $52 \%$ for the $\mathrm{c} 9, \mathrm{t} 11$ isomer, whereas the transfer efficiencies for the other isomers were $10 \%$ lower [2]. These findings coincide with experimental data of a rat study from Sugano et al. [35], reporting that lymphatic absorption of CLA is lower than that of linoleic acid and differs for individual CLA isomers (trans-trans $>$ cis-trans $>$ trans-cis). The present results confirm data presented by Kramer et al. [21] that incorporation of the five CLA isomers does not seem to be adipose tissue specific, since the distribution pattern was similar in the BFO, BFI and OF.

\subsection{Lipid content and fatty acid profile of the longissimus dorsi muscle}

Total lipid content of the LD muscle was not affected by the dietary treatments (Tab. VIII) and our results are in agreement with those recently reported by Warnants et al. [38]. By contrast, the data of our study did not confirm data from Dugan and coworkers [13] which demonstrated $22 \%$ increased petroleum-ether-extractable intramuscular fat (IMF) content in longissimus thoracis in pigs fed a diet supple- mented with CLA compared to those receiving a sunflower oil-enriched diet. As reported for the fat tissues, a shift towards a higher degree of saturation due to CLA inclusion could also be found in the IMF, even though this was less evident. Myristic, palmitic, total SFA and palmitoleic acid tissue levels were increased and oleic, eicosenoic and eicosadienoic acid were decreased in the CLA group, compared to the SO and LA group. By contrast, the concentration of the total PUFA was not affected by the dietary fat supply. Except for oleic acid and total MUFA content, the fatty acid profiles of the muscle lipids were similar among animals fed the SO and LA diets, confirming the fact that fatty acid composition of the IMF is less susceptible to the dietary fat pattern [38]. Neither total lipid content nor the fatty acid profile of muscle lipids was affected by sex.

Except for the c10,c12 isomer, which was not present in the muscle lipids of the CLA group (Fig. 1), the relative amounts of the individual isomers $\left(\mathrm{g} \cdot 100 \mathrm{~g}^{-1}\right.$ total CLA) was similar to those in the fat tissues (Fig. 2) and did not differ between sexes. However, compared to the adipose tissue $\sim 67 \%$ lower total CLA concentrations were found in the IMF. The CLA content has been reported to be higher in the neutral lipid (3-6\%) than in the complex lipid fraction (1-2\%) [21] and could therefore partly explain the lower CLA content of the muscle fat, because $15 \%$ of total IMF belongs to the complex lipid subfraction [6]. Tissue fatty acid composition is a dynamic system constantly receiving, oxidizing, and incorporating dietary and de novo synthesized fatty acids. Compared to the adipose tissue, the metabolic turnover in the intramuscular fat is higher [28] and therefore differences in CLA incorporation might also be due to differences in the turnover rate and/or CLA isomers might be discriminated against the synthesis of muscle tissue lipids. 
Table VIII. Fat content and fatty acid profile of the longissimus dorsi muscle as affected by dietary fatty acids ${ }^{1}$.

\begin{tabular}{|c|c|c|c|c|}
\hline \multirow[b]{2}{*}{ Item } & \multicolumn{4}{|c|}{ Treatment $^{2}$} \\
\hline & CLA & SO & LA & SEM \\
\hline Lipid $\left(g \cdot 100 g^{-1}\right)$ & 1.98 & 1.77 & 1.89 & 0.35 \\
\hline \multicolumn{5}{|c|}{ Fatty acid $\left(\mathrm{g} \cdot 100 \mathrm{~g}^{-1} \text { total fatty acids }\right)^{3}$} \\
\hline 14:0 & $1.71^{\mathrm{b}}$ & $1.37^{\mathrm{a}}$ & $1.38^{\mathrm{a}}$ & 0.05 \\
\hline $16: 0$ & $27.60^{\mathrm{b}}$ & $24.98^{\mathrm{a}}$ & $24.66^{\mathrm{a}}$ & 0.48 \\
\hline 18:0 & 12.17 & 11.57 & 11.05 & 0.35 \\
\hline SFA & $41.70^{\mathrm{b}}$ & $38.21^{\mathrm{a}}$ & $37.34^{\mathrm{a}}$ & 0.85 \\
\hline $16: 1(n-7)$ & $5.30^{\mathrm{b}}$ & $4.03^{\mathrm{a}}$ & $4.29^{\mathrm{a}}$ & 0.15 \\
\hline $18: 1(n-9)$ & $38.89^{\mathrm{a}}$ & $41.79^{b}$ & $44.67^{\mathrm{c}}$ & 0.73 \\
\hline $20: 1(n-9)$ & $0.45^{\mathrm{a}}$ & $0.62^{\mathrm{b}}$ & $0.63^{\mathrm{b}}$ & 0.04 \\
\hline MUFA & $44.87^{\mathrm{a}}$ & $46.64^{\mathrm{a}}$ & $49.86^{\mathrm{b}}$ & 0.80 \\
\hline $18: 2(n-6)$ & 8.74 & 11.35 & 8.98 & 0.76 \\
\hline $\mathrm{CLA}^{4}$ & 1.49 & $\mathrm{ND}^{5}$ & ND & 0.04 \\
\hline $20: 2(n-6)$ & $0.18^{\mathrm{a}}$ & $0.31^{\mathrm{b}}$ & $0.26^{\mathrm{b}}$ & 0.02 \\
\hline $20: 4(n-6)$ & 1.67 & 2.06 & 2.04 & 0.27 \\
\hline $18: 3(n-3)$ & 0.32 & 0.31 & 0.34 & 0.01 \\
\hline $20: 5(n-6)$ & 0.17 & 0.05 & 0.13 & 0.03 \\
\hline $22: 4(n-6)$ & 0.23 & 0.33 & 0.29 & 0.03 \\
\hline $22: 6(n-6)$ & 0.30 & 0.22 & 0.25 & 0.05 \\
\hline PUFA & 13.43 & 15.15 & 12.81 & 1.20 \\
\hline $16: 1(n-7) / 16: 0$ & $0.19^{\mathrm{b}}$ & $0.16^{\mathrm{a}}$ & $0.17^{\mathrm{a}}$ & 0.01 \\
\hline $18: 1(n-9) / 18: 0$ & 3.21 & 3.64 & 4.07 & 0.14 \\
\hline
\end{tabular}

${ }^{1}$ Results are presented as least-square means $(n=8)$ and standard error of the mean (SEM).

2 a,b,c Least-square means within a row not sharing a common superscript differ $(P<0.05)$.

${ }^{3}$ Fatty acids are designated by the number of carbon atoms followed by the number of double bonds. The position of the first double-bond relative to the methyl $(n)$ end of the molecule is also indicated. The sums of the main fatty acid series are represented as: SFA = saturated fatty acids, MUFA $=$ monounsaturated fatty acids, PUFA $=$ polyunsaturated fatty acids .

${ }^{4}$ Sum of c9,t11; c9,c11; t10,t12; c10,c12 and t9,t11/t10,t12 18:2 isomers.

${ }^{5} \mathrm{ND}$, not detected.

\section{CONCLUSIONS}

In the present communication, we clearly demonstrated that compared to other dietary fats, CLA inclusion dramatically elevated the degree of saturation of the adipose and muscle tissue lipids in pigs. We postulate, that this effect was mainly a result of a distinct down-regulation of the stearoyl-CoA desaturase activity. In accordance with the results of the carcass measurements, lipogenesis did not seem to be affected. 
Figure 1. CLA content $\left(\mathrm{g} \cdot 100^{-1} \mathrm{~g}\right.$ total fatty acids) of the fat tissues [back fat outer layer (BFO), back fat inner layer (BFI), omental fat $(\mathrm{OF})]$ and longissimus dorsi muscle (LD)] of animals fed diets supplemented with CLA. CLA isomers were c9,t11; $\mathrm{t} 10, \mathrm{c} 12 ; \mathrm{t} 9, \mathrm{t} 11 / \mathrm{t} 10, \mathrm{t} 11 ;$ c9,c11; c10,c12. The values are expressed as means $\pm \operatorname{SEM}(n=8)$.

Figure 2. CLA distribution pattern $\left(\mathrm{g} \cdot 100^{-1} \mathrm{~g}\right.$ total CLA) in the fat tissues [back fat outer layer: BFO; back fat inner layer: BFI; omental fat: OF] and longissimus dorsi muscle [LD] of animals fed diets supplemented with CLA (CLA). The values are expressed as means $(n=8)$.
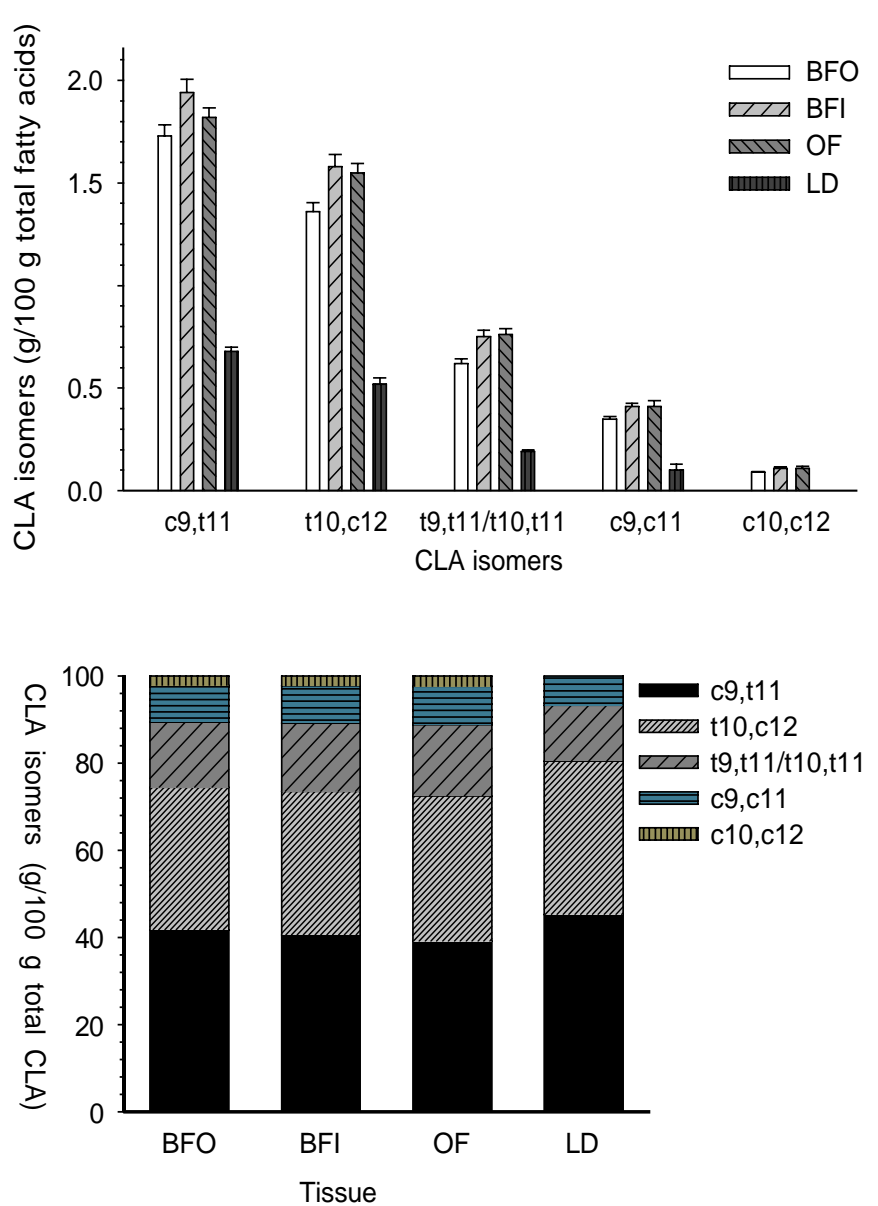

\section{ACKNOWLEDGMENTS}

The author is grateful for the donation of the CLA- and linoleic-enriched oil by Grünau Jllertissen $\mathrm{GmbH}$, Germany. I would also like to thank Merlin D. Lindemann from the University of Kentucky for the review of the manuscript and to Marcel Barman, Guy Maïkoff, Peter Stoll, Silviane Veuthey-Gentil, and Fritz Wüthrich for their excellent technical assistance.

\section{REFERENCES}

[1] Azain M.J., Hausman D.B., Sisk M.B., Flatt W.P., Jewell D.E., Dietary conjugated linoleic acid reduces rat adipose tissue cell size rather than cell number, J. Nutr. 130 (2000) 1548-1554.
[2] Bee G., Dietary conjugated linoleic acids (CLA) alter adipose tissue and milk lipids of pregnant and lactating sows, J. Nutr. 130 (2000) 2292-2298.

[3] Bee G., Dietary conjugated linoleic acids (CLA) consumption during pregnancy and lactation influence growth and tissue composition in weaned pigs, J. Nutr. 130 (2000) 2981-2989.

[4] Bee G., Messikommer R., Gebert S., Dietary fats and energy levels differently affect tissue lipogenic enzyme activity in finishing pigs, Fett/Lipid 101 (1999) 336-342.

[5] Bee G., Wenk C., Einfluss der Fettsäuren im Futter auf die Fettsäuren im Gesamtkörper beim Schwein, J. Anim. Physiol. Anim. Nutr. 66 (1991) 122 (Abstr.).

[6] Bee G., Wenk C., Effect of soybean oil and beef tallow supplementation to pig diets on the fatty acid profile of body lipids, J. Anim. Physiol. Anim. Nutr. 71 (1994) 277-288. 
[7] Belury M.A., Kempa-Steczko A., Conjugated linoleic acid modulates hepatic lipid composition in mice, Lipids 32 (1997) 199-204.

[8] Blake W.L., Clarke S.D., Suppression of rat hepatic fatty acid synthase and S14 gene transcription by dietary polyunsaturated fat, J. Nutr. 120 (1990) 1727-1729.

[9] Boltshauser M., Jost M., Kessler J., Stoll P., Fütterungsempfehlungen und Nährwerttabellen für Schweine. Landwirtschaftliche Lehrmit telzentrale, Zollikofen, Switzerland, 1993.

[10] Buller K.J., Enser M., The effect of food intake and dietary fatty acids on the activity of stearoylCoA $\Delta 9$ desaturase in pig adipose tissue, J. Agric. Sci. 106 (1986) 601-609.

[11] Clarke S.D., Jump D.B., Regulation of gene transcription by polyunsaturated fatty acids, Prog. Lipid Res. 32 (1993) 139-149.

[12] Clarke S.D., Jump D.B., Polyunsaturated fatty acid regulation of hepatic gene transcription, J. Nutr. 126 (1996) 1105-1109.

[13] Dugan M.E.R., Aalhus J.L., Jeremiah L.E., Kramer J.K.G., Schaefer A.L., The effects of feeding conjugated linoleic acid on subsequent pork quality, Can. J. Anim. Sci. 79 (1999) 45-51.

[14] Dugan M.E.R., Aalhus J.L., Schaefer A.L., Kramer J.K.G., The effect of conjugated linoleic acid on fat to lean repartitioning and feed conversion in pigs, Can. J. Anim. Sci. 77 (1997) 723-725.

[15] Eggert J.M., Carroll A.L., Richert B.T., Gerrard D.E., Forrest J.C., Bowker B.C., Effects of high oil corn and duration of conjugated linoleic acid (CLA) supplementation on pig growth, pork quality and carcass composition, J. Anim. Sci. (Suppl. 1) 77 (1999) 179 (Abstr.).

[16] Eggert J.M., Carroll A.L., Richert B.T., Gerrard D.E., Forrest J.C., Bowker B.C., Wynveen E.J., Effects of conjugated linoleic acid (CLA) on the growth, carcass composition and pork quality of two genotypes of lean gilts, J. Anim. Sci. (Suppl. 1) 77 (1999) 178 (Abstr.).

[17] Honikel K.O., Reference methods for the assessment of physical characteristics of meat, Meat Sci. 49 (1998) 447-457.

[18] Hsu R.Y., Lardy H.A., Malic enzyme, Methods Enzymol. 13 (1969) 230-235.

[19] Klingenberg I.L., Knabe D.A., Smith S.B., Lipid metabolism in pigs fed beef tallow or high-oleic acid sunflower oil, Comp. Biochem. Physiol. 110 (1995) 183-192.

[20] Kouba M., Mourot J., Effect of a high linoleic acid diet on $\Delta 9$-desaturase activity, lipogenesis and lipid composition of pig subcutaneous adipose tissue, Reprod. Nutr. Dev. 38 (1998) 31-37.

[21] Kramer J.K.G., Sehat N., Dugan M.E.R., Mossoba M.M., Yurawecz M.P., Roach J.A., Eulitz K., Aalhus J.L., Schaefer A.L., Ku Y., Distributions of conjugated linoleic acid (CLA) isomers in tissue lipid classes of pigs fed a commercial CLA mixture determined by gas chromatography and silver ion-high-performance liquid chromatography, Lipids 33 (1998) 549-558.

[22] Leveille G.A., Adipose tissue metabolism: influence of periodicity of eating and diet composition, Fed. Proc. 29 (1970) 1294-1301.

[23] Metcalfe L.D., Smith J.F., The rapid preparation of fatty acid esters for gas chromatographic analyses, Anal. Chem. 33 (1961) 363-364.

[24] Morgan C.A., Noble R.C., Cocchi M., McCartney R., Manipulation of the fatty acid composition of pig meat lipids by dietary means, J. Sci. Food Agric. 58 (1992) 357-368.

[25] Mourot J., Kouba M., Peiniau P., Comparative study of in vitro lipogenesis in various adipose tissues in the growing domestic pig (Sus domesticus), Comp. Biochem. Physiol. B 111 (1995) 379-384.

[26] Nakamura M.T., Cho H.P., Clarke S.D., Regulation of hepatic delta- 6 desaturase expression and its role in the polyunsaturated fatty acid inhibition of fatty acid synthase gene expression in mice, J. Nutr. 130 (2000) 1561-1565.

[27] Ostrowska E., Muralitharam M., Cross R.F., Bauman D.E., Dunshea F.R., Dietary conjugated linoleic acids increase lean tissue and decrease fat deposition in growing pigs, J. Nutr. 129 (1999) 2037-2042.

[28] Otten W., Wirth C., Iaizzo P.A., Eichinger H.M. A high omega 3 fatty acid diet alters fatty acid composition of heart, liver, kidney, adipose tissue and skeletal muscle in swine, Ann. Nutr Metab. 37 (1993) 134-141.

[29] Rebsamen A., Schwörer D., Lorenz D., Die Schlachtkörperzerlegung beim Schwein in der MLP Sempach, Der Kleinviehzüchter 43 (1995) 223-259.

[30] Roncari D.A., Fatty acid synthase from human liver, Methods Enzymol. 71 (1981) 73-79.

[31] SAS Institute Inc., SAS User's Guide: Statistics, Version 8.00, SAS Institute, Cary, NC, 2000

[32] Scheeder M.R.L., Bossi H., Wenk C., Kritische Betrachtungen zur Fettzahl-Bestimmung, Agrarforschung 6 (1999) 1-8.

[33] Smith D.R., Knabe D.A., Smith S.B., Depression of lipogenesis in swine adipose tissue by specific dietary fatty acids, J. Anim. Sci. 74 (1996) 975-983.

[34] Sparks J.C., Wiegand B.R., Parrish F.C., Zimmerman D.R., Effects of length of feeding conjugated linoleic acid (CLA) on growth and body composition of pigs, J. Anim. Sci. (Suppl. 1) 77 (1999) 178 (Abstr.)

[35] Sugano M., Tsujita A., Yamasaki M., Yamada K., Ikeda I., Kritchevsky D., Lymphatic recovery, tissue distribution, and metabolic effects of conjugated linoleic acid in rats, J. Nutr. Biochem. 8 (1997) 38-43. 
[36] Thiel R.L., Sparks J.C., Wiegand B.R., Parrish F.C., Ewan R.C., Conjugated linoleic acid improves performance and body composition in swine, J. Anim. Sci. (Suppl. 2) 76 (1998) 57 (Abstr.).

[37] Warnants N., Van Oeckel M.J., Boucque C.V., Effect of incorporation of dietary polyunsaturated fatty acids in pork backfat on the quality of salami, Meat Sci. 49 (1998) 435-445.

[38] Warnants N., Van Oeckel M.J., Boucque C.V., Incorporation of dietary polyunsaturated fatty acids into pork fatty tissues, J. Anim. Sci. 77 (1999) 2478-2490.
[39] Warnants N., Van Oeckel M.J., Boucque C. Incorporation of dietary polyunsaturated fatty acids in pork tissues and its implications for the quality of the end products, Meat Sci. 44 (1996) $125-144$

[40] Winter E., Über ein neues Verfahren zur Bestimmung und Untersuchung von Fetten in Lebensmitteln, Z. Lebensm. Unters. Forsch. 123 (1963) 205-210.

[41] Wood J.D., Fat deposition and the quality of fat tissue in meat animals, in: Wiseman J. (Ed.), Fats in animal nutrition, Butterworths, London, UK, 1984, pp. 407-435. 